\title{
DETERMINATION TO VOLATILE COMPONENTS AND ETHNOBOTANICAL PROPERTIES OF DIFFERENT REAPING TIMES FOR ORIGANUM VULGARE SUBSP. VIRIDE (BOISS.) HAYEK, NATURAL DISTRIBUTED IN AKSEKI (ANTALYA) PROVINCE, TURKEY
}

\author{
Ayşe Gül SARIKAYA ${ }^{1 *}$, Güliz TÜRKMENOĞLU² ${ }^{2}$ Hüseyin FAKIR ${ }^{3}$ \\ ${ }^{1 * B}$ Bursa Technical University, Faculty of Forestry, Forest Engineering Department, Bursa, Turkey; \\ ${ }^{2}$ Alanya Alaaddin Keykubat University, Akseki Vocational School, Akseki-Antalya, Turkey; \\ ${ }^{3}$ Isparta University of Applied Sciences, Faculty of Forestry, Forest Engineering Department, Isparta, Turkey; \\ *Corresponding Author Ayşe Gül SARIKAYA,e-mail: aysegul.sarikaya@btu.edu.tr;
}

Received September 2020; Accepted October 2020; Published November 2020;

DOI: https://doi.org/10.31407/ijees10.422

\begin{abstract}
In this study that was conducted in 2018-2020 vegetation period, 49 different volatile components were determined from samples of Origanum vulgare subsp. viride leaves and flowers, which were collected in 2 different periods: pre-flowering (May) and flowering (June) by SPME (solid-based micro extraction) method. 39 different components were detected in the pre-flowering period (May) and the main components were Linalool (89.02\%), Caryophyllene $(2.76 \%)$ and . $\beta .-M y r c e n e ~(2.57 \%)$, while in the flowering period (June) 42 Different components were determined and the main components were determined with the ratios of Linalool $(89,02 \%)$, Caryophyllene $(2,76 \%)$ and .B.Myrcene (2,57\%). In order to determine the ethnobotanical characteristics of Origanum vulgare subsp. viride, a survey of 15 questions was conducted with 41 people living in Akseki district with different demographic characteristics, using face-to-face interview method. $68 \%$ of the participants consume thyme plant for health and treatment purposes, and $88 \%$ for food / meal / spice purposes. $68 \%$ of the participants were found to drink thyme tea or consume it as a spice to add flavor to their meals.
\end{abstract}

Keywords: Origanum vulgare subsp. viride, Volatile component, Ethnobotany, Linalool, Spice and tea plant 